\title{
Diabetic retinopathy in two patients with congenital IGF-I deficiency (Laron syndrome)
}

\author{
Zvi Laron and Dov Weinberger ${ }^{1}$ \\ Endocrinology and Diabetes Research Unit, Schneider Children's Medical Center, Petah Tikva, WHO Collaborating Center for the Study of Diabetes in Youth \\ and ${ }^{1}$ Department of Ophthalmology, Rabin Medical Center, Beilinson Campus, Petah Tikva and Sackler School of Medicine, Tel Aviv University, Tel Aviv,
} Israel

(Correspondence should be addressed to Zvi Laron, Endocrinology and Diabetes Research Unit, Schneider Children's Medical Center of Israel, 14 Kaplan Street, Petah Tikva 49202, Israel; Email: laronz@clalit.org.il)

\begin{abstract}
Objective: Animal and clinical studies have shown that excessive amounts of growth hormone or insulin-like growth factor-I (IGF-I) promote the development of diabetes and diabetic retinopathy. Forthwith, we present two patients with congenital IGF-I deficiency who developed type II diabetes and subsequently retinopathy.

Methods: Eighteen adult patients with classical Laron syndrome (8 males, 10 females, aged 20-62 years) were followed by us since childhood or underwent fundus photography with a Nikon NF 505 instrument. Three had been treated in childhood with IGF-I, the rest were never treated, including the two patients reported.

Results: Two never-treated patients were diagnosed with type II diabetes (DM) at ages 39 and 41 respectively. There was no diabetes in the families. Oral treatment was followed by insulin injections. Metabolic control was not optimal and one patient developed proliferative diabetic retinopathy, necessitating laser surgery. He also has nephropathy and severe neuropathy. The other patient has background diabetic retinopathy and has developed, progressively, exudates, microaneurisms, hemorrhages and clinically significant macular edema. He also has subacute ischemic heart disease. Conclusions: Our findings show that congenital IGF-I deficiency, similar to excess, causes vascular complications of DM, denoting also that vascular endothelial growth factor can induce neovascularization in the presence of congenital IGF-I deficiency.
\end{abstract}

European Journal of Endocrinology 151 103-106

\section{Introduction}

Houssay observed that hypophysectomy modified experimentally induced diabetes (1) and Young showed that administration of purified pituitary growth hormone $(\mathrm{GH})$ produced diabetes (2). Subsequently, studies have been extended to insulin-like growth factor-I (IGF-I), the anabolic effector hormone of $\mathrm{GH}$ and its binding proteins (3-6). The relationship between pituitary growth hormone, diabetes and its vascular complications has recently been reviewed (7). It was observed that excessive GH secretion, such as in acromegaly induced diabetes and ketoacidosis $(8-10)$, and that in several instances acromegaly is accompanied by severe diabetic retinopathy (11-13). Treatment of acromegaly reduced the insulin requirement, improved the glucose intolerance (14) and induced regression of the retinopathy (13). It is assumed that IGF-I is involved in the development of the retinopathy. Thus, Dills et al. (15) found an association between diabetic retinopathy and elevated serum IGF-I levels. Inokuchi et al. (12) reported increased
IGF-I levels in the vitreous of their acromegalic patient with diabetic retinopathy. Increased serum IGF-I levels were also reported with progressive diabetic retinopathy during pregnancy (16). It is not settled whether IGF-I has a direct effect on angiogenesis or whether this effect is mediated via the vascular endothelial growth factor (VEGF) (17).

\section{Patient reports}

In this paper, we present two patients who developed diabetes and diabetes vascular complications despite suffering from congenital isolated deficiency of IGF-I (Laron syndrome $=$ primary GH insensitivity or resistance) due to mutations in the growth hormone receptor and thus an inability to generate IGF-I $(18,19)$.

\section{Patient 1}

A male of Jewish Iraqi origin was referred to us with two of his children, all three suffering from classical 
Laron syndrome (18) (patient \#22 in that report). His adult height was $142 \mathrm{~cm}$. He was obese: weight $61 \mathrm{~kg}$, skinfolds: iliac $22 \mathrm{~mm}$, triceps $19 \mathrm{~mm}$, subscapular $28 \mathrm{~mm}$, and his serum cholesterol was $278 \mathrm{mg} / \mathrm{dl}$. DNA analysis revealed a homozygous mutation $\mathrm{G} \rightarrow \mathrm{A}$ at position 83 (W-15X in the signal peptide) and a homozygous mutation $\mathrm{G} \rightarrow \mathrm{A}$ at position 686 (R211H in exon 7) (20). At age 39 diabetes mellitus was diagnosed (fasting glucose: $241 \mathrm{mg} / \mathrm{dl}$ (13.3 mmol/l); HbA1c: 12.4\%). Oral therapy with Phenformin (DBI) $50 \mathrm{mg}$ was instituted but his metabolic control was not consistent and at age 50 the first signs of non proliferative diabetic retinopathy (NPDR) were detected. He refused insulin therapy and after one year of oral anti-diabetic treatment (Metformin, or Glibenclamide, or Rosiglitazone) fundi examinations revealed exudates, microaneurysms, hemorrhages and clinically significant macular edema which was treated by grid laser macular photocoagulation. His metabolic control was bad (HbA1c: 10.5$12.5 \%)$. At that stage he accepted insulin treatment (neutral protamine Hagedorn insulin (NPH) bid, regular insulin (RI) tid. He subsequently developed neuropathy and partial arterial occlusion of the lower limbs. There was no evidence of diabetic nephropathy. His blood pressure was usually $150 / 80 \mathrm{~mm} \mathrm{Hg}$. He had smoked a few cigarettes a day but later claimed to have stopped.

\section{Patient 2}

A male of Jewish Yemenite origin (patient \#10 in ref. 18) belonging to a consanguineous family was diagnosed with Laron syndrome as an infant. The molecular defect of his $\mathrm{GH}$ receptor is a homozygous mutation $\mathrm{C} \rightarrow \mathrm{T}$ in position 703 ( $\mathrm{R} 217 \mathrm{X}$ in exon 7 ). His adult height is $116 \mathrm{~cm}$, with obesity, his skinfolds being over $25 \mathrm{~mm}$. At age 38 diabetes mellitus was diagnosed. Dietary management was irregular as was his metabolic control, and at age 43 he had a fasting blood glucose of $283 \mathrm{mg} / \mathrm{dl}$ and a HbA1c of $10.3 \%$. He was found to have background retinopathy including venous congestion, microaneurysms and blot hemorrhages (Fig. 1) followed within 2 years by clinically significant macular edema including hard exudates (Fig. 2). He was also diagnosed with microalbuminuria $(25 \mathrm{mg} / 24 \mathrm{~h})$ and subacute ischemic heart disease. His blood pressure varied around 140/70 mm. He smoked rarely.

There were no subjects with diabetes in the families of the two patients.

\section{Discussion}

The contribution of IGF-I in the physiology and pathophysiology of the retinal vessels is as yet unclear. The evidence in man linking GH and IGF-I to diabetic

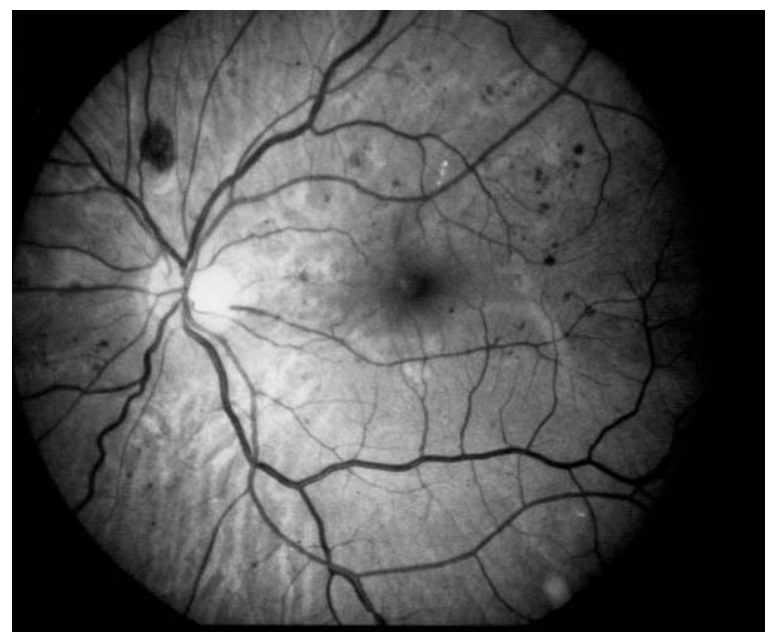

Figure 1 Red-free fundus photography of the left eye. Venous congestion, dot hemorrhages and microaneurysms can be seen.

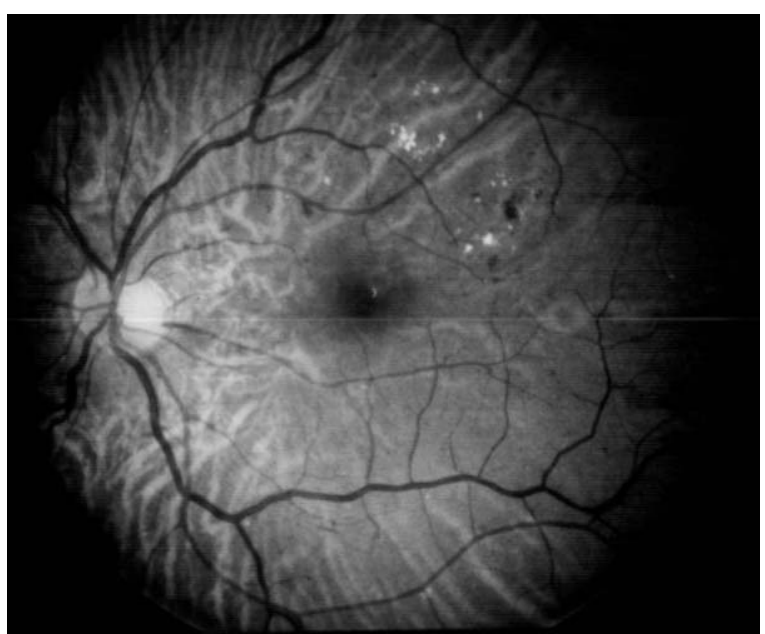

Figure 2 Red-free fundus photography of the left eye. A progression of the diabetic retinopathy including macular edema hard exudates can be seen.

retinopathy correlates eye pathology to the circulating levels of these hormones without taking into account local IGF-I production and/or action. Experimental studies using the anoxia model in mice showed that IGF-I and VEGF co-action promote retinal neovascularization (21) and that IGF-I receptor antagonist suppresses VEGF-induced neovascularization in vivo by reducing the $\mathrm{P} 44 / 42$ nitrogen-activated protein kinase (22).

Recent studies using the oxygen-induced retinopathy model in mice showed that knock out $(\mathrm{KO})$ of the IGF-I receptor decreased retinal neovascularization by $34 \%$ as compared with controls. Insulin receptor KO reduces retinal vascularization by $57 \%$ (23). These results were interpreted to mean that both IGF-I and insulin signaling in endothelium play a role in retinal neovascularization. 
In view of the experimental findings, the development of diabetic retinopathy in our two patients was unexpected. Patients with Laron syndrome have extremely low to undetectable IGF-I levels due to molecular defects of the $\mathrm{GH}$ receptor $(18,24)$. In addition to dwarfism, untreated patients have progressive obesity (25), insulin resistance and glucose intolerance (26) with occasional development of clinical diabetes, as in the two patients described. This is the first report describing diabetic retinopathy and vasculopathy in association with isolated IGF-I deficiency. These patients differ from the patient reported by Raben et al. (27), a 26-year-old patient with idopathic hypopituitarism and diabetes after pancreatectomy who developed retinal hemorrhages without neovascularization, as well as cataracts. Another patient reported by Thivolet et al. (28) had diabetes and developed multiple pituitary insufficiency by hemorrhagic shock during pregnancy. Four years later retinal neovascularization was detected, as were cataracts. In a previous study it has been shown that genetic IGF-I deficiency, including that seen in our patients, resulted in a lower number of vascular branching points in the retina (29).

Thus the role of GH/IGF-I in the development of diabetic retinopathy is not clearly defined. It seems to be U-shaped, as both GH/IGF-I excess as well as GH/IGF-I deficiency can promote diabetic retinopathy.

The action of IGF-I may also depend on genetic factors and/or metabolic changes in the retinal epithelium affecting oxygenation, VEGF and P44/42 protein kinase activity. Considering that IGF-I administration to patients with diabetes improves diabetes control by increasing insulin sensitivity and decreasing secondary GH resistance $(30,31)$, one might speculate that IGF-I is not having a 'causal' but instead either a 'permissive' mediating or even a 'protective' role (32) in the development of diabetic retinopathy.

\section{Acknowledgements}

We thank Mrs Vivian Dagan for preparing the photographs and Mrs Gila Waichman for her secretarial help.

\section{References}

1 Houssay BA. Carbohydrate metabolism. New England Journal of Medicine $1936214971-986$.

2 Young FG. Permanent experimental diabetes produced by pituitary (anterior lobe) injections. Lancet 19372 372-374.

3 Merimee TJ, Zapf J \& Froesch ER. Insulin-like growth factors. Studies in diabetics with and without retinopathy. New England Journal of Medicine 1983309 527-530.

4 Grant MB, Mames RN, Fitzgerald C, Ellis EA, Aboufriekha M \& Guy J. Insulin-like growth factor I acts as an angiogenic agent in rabbit cornea and retina: comparative studies with basic fibroblast growth factor. Diabetologia $199336291-292$.

5 Thrailkill K. Insulin-like growth factor I in diabetes mellitus: its physiology, metabolic effects, and potential clinical utility. Diabetes Technology and Therapeutics 20002 69-80.
6 Krsek M, Prazny M, Marek K, Skrha J, Justova V \& Lacinova Z. The relationship between serum levels of insulin-like growth factor-I and its binding proteins and microvascular function in acromegalic patients. Growth Hormone and Insulin-Like Growth Factor Research 200212 54-59.

7 Rehman HU. The role of growth hormone in the pathogenesis of vascular complications of diabetes mellitus. American Journal of Medical Science $2000320128-134$.

8 Coggeshall C \& Root HF. Acromegaly and diabetes mellitus. Endocrinology $1940261-25$.

9 Abrahamson MJ. Death from diabetic ketoacidosis after cessation of octreotide in acromegaly. Lancet $1990336318-319$.

10 Katz JR, Edwards R, Khan M \& Conway GS. Acromegaly presenting with diabetic ketoacidosis. Postgraduate Medical Journal 1996 72 682-683.

11 Amemiya T, Toibana M, Hashimoto M, Oseko F \& Imura H. Diabetic retinopathy in acromegaly. Ophthalmologica $1978 \mathbf{1 7 6}$ $74-80$.

12 Inokuchi N, Ikeda T, Yasuda F, Shirai S \& Uchihori Y. Severe proliferative diabetic retinopathy associated with acromegaly. Letter to the Editor. British Journal of Ophthalmology 199983628.

13 Tran HA, Petrovsky N \& Field AJ. Severe diabetic retinopathy: a rare complication of acromegaly. Internal Medicine Journal 2002 $3252-54$.

14 Nabarro JDN. Acromegaly. Clinical Endocrinology 198726 $481-512$.

15 Dills DG, Moss SE, Klein R \& Klein BE. Association of elevated IGFI levels with increased retinopathy in late-onset diabetes. Diabetes $1991401725-1730$.

16 Lauszus FF, Klebe JG, Bek T \& Flyvbjerg A. Increased serum IGF-I during pregnancy is associated with progression of diabetic retinopathy. Diabetes $2003 \mathbf{5 2} 852-856$.

17 Dunn SE. Insulin-like growth factor I stimulates angiogenesis and the production of vascular endothelial growth factor. Growth Hormone and Insulin-Like Growth Factor Research 2000 (Suppl A) S41-S42.

18 Laron Z, Pertzelan A \& Karp M. Pituitary dwarfism with high serum levels of growth hormone. Israel Journal of Medical Sciences $19684883-894$.

19 Laron Z. Laron syndrome (primary growth hormone resistance or insensitivity). The personal experience 1958-2003. Journal of Clinical Endocrinology and Metabolism 200489 1031-1044.

20 Shevah O, Rubinstein M \& Laron Z. Molecular etiology of Laron syndrome patients from different ethnic groups studied in Israel: new and old molecular defects. Hormone Research 200360 (Suppl 2) 43-44 (Abstract P1-150).

21 Smith LE, Kopchick JJ, Chen W, Knapp J, Kinose F, Daley D et al. Essential role of growth hormone in ischemia-induced retinal neovascularization. Science 1997276 1706-1708.

22 Smith LE, Shen W, Perruzzi C, Soker S, Kinose F, Xu X et al. Regulation of vascular endothelial growth factor-dependent retinal neovascularization by insulin-like growth factor-1 receptor. Nature Medicine $199951390-1394$.

23 Kondo T, Vicent D, Suzuma K, Yanagisawa M, King GL, Holzenberger $\mathrm{M}$ et al. Knockout of insulin and IGF-I receptors on vascular endothelial cells protects against retinal neovascularization. Journal of Clinical Investigation 2003111 1835-1842.

24 Laron Z. Growth hormone resistance (Laron syndrome). In Hormone Resistance and Hypersensitivity States, ch. 17, pp 251-267. Ed G Chrousos. New York: Lippincott Williams \& Wilkins, 2002.

25 Laron Z \& Klinger B. Body fat in Laron syndrome patients: effect of insulin-like growth factor treatment. Hormone Research 199340 $16-22$.

26 Laron Z, Avitzur Y \& Klinger B. Carbohydrate metabolism in primary GH resistance (Laron syndrome) before and during IGF-I treatment. Metabolism 199544 (Suppl 4) 113-118.

27 Raben D, Bloomgarden ZT, Feman SS \& Davis TQ. Development of diabetic complications despite the absence of growth hormone in a patient with post-pancreatectomy diabetes. New England Journal of Medicine $1984310837-839$. 
28 Thivolet CH, Mirakian P, Chatelain P, Fournier P \& Tourniaire J. Proliferative retinopathy in a woman with growth hormone deficiency and diabetes mellitus. British Medical Journal 1990 300 979-980.

29 Hellstrom A, Carlsson B, Niklasson A, Segnestam K, Boguszewski M, de Lacerda L et al. IGF-I is critical for normal vascularization of the human retina. Journal of Clinical Endocrinology and Metabolism 200287 3413-3416.

30 Laron Z. Growth hormone, insulin-like growth factor I and diabetes mellitus. Bailliere's Clinical Paediatrics $19964729-740$.

31 Moses AC. Recombinant human insulin-like growth factor as a therapeutic agent for severe insulin resistance and type II diabetes mellitus. Journal of Pediatric Endocrinology and Metabolism 1997 10 (Suppl 1) 123-130.

32 Janssen JAMJL \& Lamberts SWJ. Circulating IGF-I and its protective role in the pathogenesis of diabetic angiopathy. Clinical Endocrinology 200051 1-9.

Received 3 December 2003

Accepted 1 April 2004 